\title{
PENGARUH CREATIVE PSYCHOLOGY CAPITAL MEMEDIASI SENSITIVITAS ETIS TERHADAP JOB PERFORMANCE
}

\author{
Syaikhul Falah ${ }^{1}$ \\ sehufalah@gmail.com
}

This study aims to analyze the psychological aspects (creative psychology capital and ethical sensitivity) to the performance. This research was conducted in several hospitals in Jayapura City. Data collection in this research is using questionnaire where respondent in this research is staff of finance or administration and program. The sampling technique used in this research is census sampling method. The number of research samples taken as many as 38 respondents. This research uses Partial Least Square (PLS) analysis technique. The result of this study shows that the developed hiptotesi significantly influence the performance.

Keywords: Psychological Capital, Ethical Sensitivity and Job Performance, hospital

\section{PENDAHULUAN}

Penelitian sektor publik di bidang kesehatan sangat menarik. Hal ini dapat dilihat dari banyaknya perhatian terhadap kinerja Rumah Sakit dalam mengelola kinerja. Manajer harus dapat mengelola rumah sakit secara efektif dan efisien untuk dapat mencapai tujuan organisasi. Untuk dapat mencapai sasaran yang diinginkan oleh manajemen, pihak rumah sakit menuntut para pegawainya agardapat meningkatkan kinerjanya. Mahoney et al(1963) dalam (Solehah, Galih, \& Tamsil, 2013)menyatakan kinerja (performance) adalah hasil kerja yang dapat dicapai oleh seseorang atau sekelompok orang dalam suatu organisasi, sesuai dengan wewenang dan tanggung jawab masing-masing dalam rangka mencapai tujuan organisasi.

Kinerja pegawai adalah hasil kerja secara kualitas dan kuantitas yang dicapai oleh seorang karyawan dalam melaksanakan tugasnya sesuai dengan tanggung jawab yang diberikan kepadanya (Singh et al., 1996) dalam (Solehah, Galih, \& Tamsil, 2013). Menurut (Liwarto \& Kurniawan,

\footnotetext{
1 Staff Dosen Jurusan Akuntansi Fakultas Ekonomi dan Bisnis Universitas Cenderawasih
} 
2015), kinerja merupakan sejumlah output dari outcomes yang dihasilkan karyawan, baik yang berbentuk materi maupun yang berbentuk non-materi. Kinerja karyawan akan diarahkan untuk mencapai tujuan organisasi secara keseluruhan. Artinya, apabila kinerja karyawan di dalam sebuah organisasi berjalan dengan baik maka akan berakibat pada pencapaian tujuan organisasi yang baik pula.

Kinerja tidak hanya tentang yang dicapai oleh individu namun juga tentang proses mencapainya. Kinerja yang tinggi dihasilkan dari perilaku yang sesuai, terutama perilaku bijaksana dan penggunaan yang efektif dari berbagai pengetahuan, skill dan kompetensi seseorang (Armstrong, 2006) dalam (Mamik \& Tadjang, 2015).

Salah satu faktor yang dapat mempengaruhi kinerja pegawaiadalah sensitivitas etis.Sensitivitas moral atau etika adalah kemampuan untuk mengidentifikasi masalah etis dan memahami konsekuensietis dari keputusan yang dibuat (Mamik \& Tadjang, 2015). Sensitivitas etika adalah kemampuan seorang akuntan dalam memahami permasalahan yang berkaitan dengan etika (Ponemon, 1990) dalam (Kartikasari 2012)sehingga dapat dikatakan bahwa sensitivitas etis merupakan kemampuan seseorang dalam mengidentifikasi masalah yang berhubungan dengan etika yaitu keyakinan memilih antara mana yang baik dan mana yang buruk agar dapat menentukan keputusan nantinya.

Faktor yang dapat berpengaruh terhadap sensitivitas etika beragam. Namun secara umum dapat diidentifikasi menjadi tiga faktor utama. Faktor utama tersebut yaitu, faktor demografis, faktor pengenalan dimensi moral dan faktor komitmen organisasi.Menurut Hunt dan Vitell (1986) dalam (Muttaqin, 2014).

Penelitian mengenai sensitivitas etis terhadap job performance belum banyak dilakukan, apalagi dengan dimasukkannya variabel baru yang diduga dapat mempengaruhi diantara keduanya, salah satunya variabel baru dalam akuntansi manajemen yaitu Creatif Psychological Capital. CrePsycap atau modal psikologis kreatif adalah konstruk baru yang 
terdiri atas teori psikologi positif dan kreatifitas, dimana Psycap merupakan istilah untuk menggambarkan potensi dan kapasitas psikologis positif yang dimiliki seseorang.

PsyCap menurut (Luthans, Youssef, \& Avolio, 2007) sebagai keadaan perkembangan psikologis positif individu yang dicirikan denganmemiliki kepercayaan diri (self efficacy) untuk mengambil dan melakukan suatu usaha yang diperlukan untuk keberhasilan tugas yang sedang dihadapi, memberikan tanggapan positif (optimism) terhadap keberhasilan sekarang dan masa mendatang, tekun dan gigih terhadap tujuan dan jika diperlukan, mengatur upaya mencapai tujuan (hope) dalam rangka mencapai keberhasilan dan jika menghadapi masalah dan kegagalan, tetap bertahan dan bangkit kembali, dan bahkan lebih kuat dari sebelumnya (resiliency) untuk mencapai kesuksesan, sedangkan menurut (Meyer \& Lancaster, 2000) dalam (Nurfaizal, 2016), kreativitas diartikan sebagai sebuah tindakan yang mengkombinasikan elemen-elemen yang belum terkombinasi sebelumnya.

Kreatifitas dapat dijadikan sebagai potensi didalam modal psikologis. Kreativitas beradaptasi dengan ide-ide konstruktif dan mekanisme baru, sehingga memberikan kontribusi positif bagaimana pandangan orang lain dan juga diri sendiri dapat menumbuhkan kreativitas yang lebih besar atau sebaliknya (Simonton, 2004) dalam (Nurfaizal, 2016). Berdasarkan latar belakang tersebut, maka rumusan masalah di dalam penelitian ini sebagai berikut: (1) Apakah sensitivitas etis berpengaruh terhadap creatif psycap?; (2) Apakah creatif psycap berpengaruh terhadap job performance?; (3) Apakah sensitivitas etis berpengaruh terhadap job performance?

\section{LANDASAN TEORI DAN PENGEMBANGAN HIPOTESIS}

\section{Teori Psikologi Positif}

Menurut Kohlberg (1971) dalam (Falah, 2006) menyebutkan bahwa teori perkembangan moral kognitif pertama kali dikemukakan oleh Dewey. 
Dewey membagi perkembangan moral menjaditiga tahap (level) sebagai berikut:

1) Tahap "premoral" atau "preconventional".Dalam tahap ini tingkah laku seseorang didorong oleh desakan yang bersifat fisikalatau sosial;

2) Tahap "conventional". Dalam tahap ini seseorang mulai menerimanilai dengan sedikit kritis, berdasarkan kepada kriteria kelompoknya.

3) Tahap"autonomous". Dalam tahap ini seseorang berbuat atau bertingkah laku sesuai denganakal pikiran dan pertimbangan dirinya sendiri dan tidak sepenuhnya menerima kriteria kelompoknya.

Asumsi-asumsi yang digunakan Kohlberg $(1971,1977)$ dalam (Falah, 2006) mengembangkan teorinya sebagai berikut: (a) bahwa kunci untuk dapat memahamitingkah laku moral seseorang adalah dengan memahami filsafat moralnya, yaknidengan memahami alasan-alasan yang melatarbelakangi perbuatannya, (b) tingkatperkembangan tersusun sebagai suatu keseluruhan cara berpikir. Setiap orang akankonsisten dalam tingkat pertimbangan moralnya, (c) konsep tingkat perkembanganmoral menyatakan rangkaian urutan perkembangan yang bersifat universal, dalam berbagai kondisi budaya.

Sesuai dengan asumsi-asumsi tersebut, konsep perkembangan moral menurut teori Kohlberg memiliki empat ciri utama. Pertama, tingkat perkembangan itu terjadi dalam rangkaian yang sama pada semua orang. Seseorang tidak pernah melompatisuatu tingkat. Perkembangannya selalu ke arah tingkat yang lebih tinggi. Kedua, tingkat perkembangan itu selalu tersusun berurutan secara bertingkat. Dengan demikian, seseorang yang membuat pertimbangan moral pada tingkat yang lebih tinggi, dengan mudah dapat memahami pertimbangan moral tingkat yang lebih rendah. Ketiga, tingkat perkembangan itu terstruktur sebagai suatu keseluruhan. Artinya, seseorang konsisten pada tahapan pertimbangan moralnya. Keempat, tingkat perkembangan ini memberi penekanan pada struktur pertimbangan moral, bukan pada isi pertimbangannya (Falah, 2006). 


\section{Sensitivitas Etis}

Sensitivitas moral atau etika adalah kemampuan untuk mengidentifikasi masalah etis dan memahami konsekuensi etis dari keputusan yang dibuat (Mamik \& Tadjang, 2015). Kemampuan seorang profesional untuk berperilaku etis sangat dipengaruhi oleh sensitivitas individu tersebut. Faktor yang penting dalam menilai perilaku etis adalah adanya kesadaran para individu bahwa mereka adalah agen moral. Kesadaran individu tersebut dapat dinilai melalui kemampuan untuk menyadariadanya nilai-nilai etis dalam suatu keputusan yang disebutkan sebagai sensitivitas etika (Velasque dan Rostankowski, 1985) dalam (Falah, 2006).

Hunt dan Vitell (1986) dalam (Muttaqin, 2014) menyatakan bahwa sensitivitas etika ini akan digunakan sebagai dasar untuk melakukan keputusan etis (Ethical Judgement).Terdapat empat komponen kerangka kerja yang telah diajukan oleh Rest(1983) dalam (Falah, 2006)untuk meneliti pengembangan proses berpikir moralindividual dan perilaku individu pada proses pengambilan keputusan dimana tiapkomponen tersebut mempengaruhi perilaku moral. Kegagalan pada komponen dapat menyebabkan perilaku yang tidak etis. Ciri-ciri komponen tersebut adalah sebagai berikut:

1) Pengenalan individu akan keberadaan masalah etis dan pengevaluasianpengaruh pilihan perilaku potensial pada kesejahteraan pihak yang terimbas

2) Penentuan perilaku moral secara ideal yang sesuai untuk sebuah situasi

3) Keputusan pada tindakan yang dimaksud berkaitan dengan berbagai hasilyang dinilai dan implikasi moralnya

4) Pelaksanaan perilaku yang dimaksud tersebut.

\section{Creatif Psychological Capital}

Kreativitas dan modal psikologi merupakan dua konstruk baru dalam akuntansi manajemen dimana kreativitas menjadi faktor penting didalam 
organisasi, terutama pada kondisi dimana organisasi menghadapi lingkungan yang kompetitif. Inisiatif dan implementasi dari ide kreatif meningkatkan kemampuan organisasi untuk merespon peluang yang ada. Peningkatan kinerja kreatif dari pekerja merupakan suatu keharusan jika organisasi ingin mencapai keunggulan kompetitifnya (Amabile, 1988) dalam (Nurfaizal, 2016).Sedangkan psycap merupakan konstruk yang dikembangkan oleh Luthans dan rekan-rekannya, untuk menangkap kapasitas psikologis individu yang dapat diukur, dikembangkan dan dimanfaatkan untuk peningkatan kinerja (Nurfaizal, 2016).

Luthans memelopori pendekatan positif dalam perilaku organisasi dengan cara memetakan perilaku organisasi positif (POB), yang fokus pada pembangunan kekuatan manusia di tempat kerja daripada hanya mengelola kelemahannya. Luthans merekomendasikan bahwa peneliti POB mempelajari keadaan psikologis yang dapat secara sah diukur dan ditempa dalam hal intervensi organisasi untuk meningkatkan kinerja. Luthans mengusulkan bahwa kondisi-kondisi seperti harapan, keyakinan dan ketahanan memenuhi kriteria tersebut (Luthans, 2002a, 2000b) dalam (Nurfaizal, 2016).

PsyCap dalam (Luthans, Youssef, \& Avolio, 2007)dinyatakan sebagai keadaan perkembangan psikologis positif individu yang dicirikan dengan:

1) memiliki kepercayaan diri (self efficacy) untuk mengambil dan melakukan suatu usaha yang diperlukan untuk keberhasilan tugas yang sedang dihadapi,

2) memberikan tanggapan positif (optimism) terhadap keberhasilan sekarang dan masa mendatang,

3) tekun dan gigih terhadap tujuan dan jika diperlukan, mengatur upaya mencapai tujuan (hope) dalam rangka mencapai keberhasilan dan

4) jika menghadapi masalah dan kegagalan, tetap bertahan dan bangkit kembali, dan bahkan lebih kuat dari sebelumnya (resiliency) untuk mencapai kesuksesan 
Terdapat empat dimensi yang menyusun Psychological capital (Luthans, Youssef \& Avolio, 2007), yaitu:

1. Efikasi Diri (Self-Efficacy).

Albert Bandura (1997), mengemukakan self-efficacy didefinisikan sebagai "kepercayaan akan kemampuan dirinya mengarahkan motivasi, sumber daya kognitif, dan tindakan yang diperlukan agar berhasil dalam melaksanakan tugas tertentu "(Stajkovic \& Luthans, 1998b, p. 66). Bandura (1997) telah mengidentifikasi empat sumber yang diakui secara luas pengembangan efficacy.

Pertama, ketika individu berhasil menyelesaikan tugas yang menantang, individu pada umumnya lebih percaya diri terhadap kemampuannya untuk menyelesaikan tugas. Kedua, personal efficacy dipengaruhi ketika individu merasakan sendiri belajar dengan cara mengamati (yaitu, modeling) dapat menyelesaikan tugas yang diberikan. Jika berhasil pada tugas yang diberikan, maka personal efficacy meningkat. Dampak dari modeling tergantung pada seberapa mirip individu melihat dirinya sendiri dengan melihat peran yang dilakuakn berhasil menyelesaikan tugas.

Jika proses meniru individu snagat mirip, maka proses pengembangan efficacy menjadi lebih efektif (Bandura, 1997). Stajkovic dan Luthans (dalam Avey, Luthans, Smiths, \& Palmer, 2010) mendefinisikan efikasi diri atau self-efficacy sebagai keyakinan diri individu terhadap kemampuan yang dimilikinya dalam mengarahkan segala usaha agar berhasil dan sukses dalam melaksanakan tugas yang dihadapinya. Individu dengan self-efficacy yang tinggi akan berani untuk menetapkan tujuan dan dapat mengendalikan diri sendiri dalam keadaan sulit, berani menerima tantangan, memiliki motivasi yang kuat, mampu mengerahkan segala usaha dalam mencapai tujuan dan tetap gigih walaupun menghadapi rintangan (Luthans, Youssef \& Avolio, 2007). Singh dan 
Manshi (2009) menyatakan bahwa individu dengan tingkat self-efficacy tinggi memiliki psychological well-being yang tinggi pula, individu akan merasa lebih percaya diri, memiliki aspirasi yang tinggi dan komitmen yang kuat terhadap apa yang ingin di capai.

\section{Harapan (Hope)}

Konstruk hope dalam psikologi positif memiliki perkembangan teoritis yang cukup pesat dan secara umum dianggap sebagai "empowering way of thinking" (Snyder, 1994, p. 2). Dalam merumuskan teori hope, Snyder dengan asumsinya, bahwa individu pada umumnya berorientasi pada tujuan yaitu individu berperilaku seperti, mencoba untuk mencapai sesuatu. Harapan atau hope didefinisikan oleh Envick (2005) sebagai hasrat atau keinginan yang disertai dengan pengharapan akan pemenuhan dari hasrat atau keinginan tersebut.

Snyder (dalam Avey, Luthans, Smiths, \& Palmer, 2010) mendefinisikan harapan sebagai positive emotional state dengan dua komponen penting yaitu (1) agency (energi untuk mencapai tujuan) dan (2) pathways (perencanaan untuk mencapai tujuan). Agency atau kekuatan keinginan merupakan kondisi kognitif dimana individu mampu menetapkan tujuan, memiliki kekuatan (energy), dan locus of control internal, sedangkan kondisi dimana individu mampu menemukan cara lain untuk mencapai tujuan yang diinginkan ketika cara pertama mengalami kendala disebut pathway.

\section{Optimisme (Optimism)}

Dalam PsyCap, optimisme adalah individu yang mengharapkan peristiwa positif dan diinginkan di masa yang akan datang (Luthans, Youssef, et al., 2007). Individu yang optimis dan kehilangan pekerjaannya akan menghubungkan penyebab kehilangan pekerjaannya ke dalam keadaaan situasi sementara. Carver dan Scheier (2002) ketika individu memiliki harapan positif, individu akan terus berusaha meskipun 
menghadapi kesulitan. Sebaliknya, individu yang pesimis adalah individu yang secara konstan memiliki pikiran yang negatif dan meyakini peristiwa yang tidak diinginkan akan terjadi. Dapat disimpulkan bahwa individu yang optimis akan melakuakan sesuatu dengan lebih baik dibandingkan dengan pesimis.

Menurut Seligman (dalam Luthans F, Luthans W, LuthansC, 2004), optimisme adalah cara menginterpretasi kejadian positif oleh individu yang digunakan dalam menjelaskan kejadian yang baik maupun yang buruk, penjelasan dari optimisme memiliki dua dimensi penting yaitu waktu (permanence) dan tempat (pervasiveness). Permanence berhubungan dengan waktu, saat terjadi kejadian buruk individu yang optimis melihat hal tersebut sebagai sesuatu yang sementara, sebaliknya individu pesimis akan melihat hal tersebut sebagai sesuatu yang permanen. Pervasiveness berhubungan dengan tempat yang memiliki penjelasan secara spesifik mengenai suatu kejadian yang buruk adalah individu yang optimis, sedangkan individu yang menjelaskan secara universal adalah individu yang pesimis.

Beberapa penelitian menunjukkan bahwa optimisme memiliki hubungan positif dengan well-being. Misalnya dalam konteks kewirausahaan ditemukan bahwa optimisme bertentangan dengan pesimis, optimis sering mengalami berbagai jenis pengalaman yang sulit (Scheier, Carver, \& Bridges, 2001).

Sedangkan pesimis cenderung mudah putus asa terhadap kesulitan yang dihadapinya, optimis dapat bertahan, siap terhadap tantangan yang diberikan, dan dapat mencapai tujuannya (Carver, \& Scheier, 2003). Individu optimis cenderung mensyukuri setiap perubahan yang terjadi, mampu melihat kesempatan yang tersedia dan fokus dalam mendapatkan kesempatan tersebut (Luthans, Youssef, \& Avolio, 2007). Singh dan Manshi (2009) melengkapi definisi dari optimismeediatas sebagai harapan atau dugaan terhadap hal yang positif, keyakinan bahwa segala sesuatau adalah baik dan akan mendapat hasil yang terbaik pula. 


\section{Resilienci (Resiliency)}

Resiliensi adalah kondisi dimana individu dapat bertahan dan bangkit kembali dari pengalaman yang negatif dan dapat beradaptasi kembali dengan adanya perubahan stress yang dihadapi (Tugade \& Fredrickaon dalam Hmieleski \& Carr, 2007). Luthans (dalam Avey, Luthans, Smiths, \& Palmer, 2010) menjelaskan resiliensi sebagai kemampuan seseorang untuk bangkit kembali saat mengalami kejadian yang tidak menyenangkan dan dapat beradaptasi kembali dari kegagalan tersebut.

Menurut Masten dan Reed (2002), resiliensi merupakan positif coping dan dapat beradaptasi kembali dari kesulitan yang dihadapi. Ketika resiliensi diterapkan di tempat kerja, dapat digambarkan sebagai positif psikologi untuk dapat bangkit kembali dari keterpurukan, ketidakpastian, konflik, kegagalan, atau bahakan perubahan positif dan meningkatnya tanggung jawab (Luthans, 2002a, p. 702). Selain itu menurut Block dan Kremen (1996), Coutu (2002), serta Masten (2001), individu yang memiliki resiliensi tinggi cenderung lebih efekti dalam berbagai pengalaman, termasuk penyesuaian. Richardson (2002) menemukan bahwa resiliensi dapat meningkat bahkan tumbuh setelah individu mengalami peristiwa buruk. Artinya bahwa individu dapat lebih resilien terhadap situasi yang merugikan dan dapat bangkit kembali dari peristiwa sebelumnya.

Kreatifitas dapat dijadikan sebagai potensi di dalam modal psikologis. Kreativitas beradaptasi dengan ide-ide konstruktif dan mekanisme baru, sehingga memberikan kontribusi positif bagaimana pandangan orang lain dan juga diri sendiri dapat menumbuhkan kreativitas yang lebih besar atau sebaliknya (Simonton, 2004) dalam (Nurfaizal, 2016).

Kunci utama PsyCap antara lain: (1) didasarkan atas paradigma psikologi positif (pentingnya semangat positif dan kekuatan / daya juang manusia), (2) termasuk di dalamnya keadaan psikologis berdasarkan 
perilaku organisasi positif, (3) melampaui human capital dan social capital (4) melibatkan investasi dan pengembangan untuk kembali menghasilkan peningkatan kinerja dan menghasilkan keunggulan kompetitif. (Avolio \& Luthans, 2005).

\section{Job Performance}

Kinerja pegawai (job performance) dapat diartikan sebagai sejauh mana seseorangmelaksanakan tanggung jawab dan tugas kerjanya. Kinerja pegawai adalah hasil kerja secara kualitas dan kuntitas yang dicapai oleh seorang karyawan dalam melaksanakan tugasnya sesuai dengan tanggung jawab yang diberikan kepadanya (Singh et al., 1996) dalam (Solehah, Galih, \& Tamsil, 2013).

Untuk meningkatkan kinerja pegawai, organisasi perlu melakukan perbaikan kinerja. Faktor yang perlu diperhatikan oleh suatu organisasi di dalam perbaikan kinerja, Mathis dan Jackson (2006: 378) dalam (Silen, 2016)menguraikan beberapa faktor yang digunakan dalam mengukur kinerja pegawai, yaitu hasil kerja, kualitas hasil kerja, ketepatan waktu kehadiran dan kemampuan bekerjasama.

Gomes (1995) dalam (Soleha, Rosiana, \& Yulianto, 2014)mengatakan kinerja pekerjaan adalahcatatan hasil atau keluaran (outcomes) yang dihasilkan dari suatufungsipekerjaan tertentu atau kegiatan tertentu dalam suatu periode waktu tertentu.Sedangkan pengukuran kinerja merupakan cara untuk mengukur tingkat kontribusi individu kepadaorganisasinya. Kinerja karyawan umumnya diposisikan sebagai variabel dependen dalam penelitian-penelitian empiris karena dipandang sebagai akibatatau dampak dari perilaku organisasi atau praktek-praktek sumber dayamanusia bukan sebagai penyebab atau determinan.

Manfaat dari penilaian kinerja digunakan untuk perbaikan prestasi kerja, penyesuaian kompensasi, kebutuhan pengembangan, serta melihat penyimpangan maupun kesalahan dalam pekerjaan. Kegunaan tersebut 
mengharuskan penilaian kinerja mampu memberikan gambaran yang akurat dan objektif mengenai prestasi kerja pegawai (Mudayana, 2010).

\section{Penelitian Terdahulu Dan Pengembangan Hipotesis}

\section{Sensitivitas Etis Terhadap Creatif Psycap}

Hunt dan Vitell (1986) dalam (Muttaqin, 2014) menyatakan bahwa sensitivitas etika ini akan digunakan sebagai dasar untuk melakukan keputusan etis (Ethical Judgement). Sensitivitas etis merupakan kemampuan seseorang dalam mengidentifikasi masalah yang berhubungan dengan etika yaitu keyakinan memilih antara mana yang baik dan mana yang buruk agar dapat menentukan keputusan nantinya.Sedangkan creatif psycap merupakan istilah yang menggambarkan seseorang yang memiliki kemampuan kreatif dan selalu berpikir positif dalam menghadapi permasalahan serta mampu untuk mencari peluang di lingkungan yang kompetitif.

Meskipun penelitian mengenai sensitivitas etis terhadap modal psikologi sejauh sepengetahuan peneliti belum ada, namun dari pengertian keduanya dapat disimpulkan bahwa sensitivitas etis diharapkan dapat mempengaruhi creatif psycap. Hal tersebut dikarenakan, ketika berada dalam lingkungan kerja, seseorang yang memiliki pemahaman etika akan mengarahkan sikap, tingkah laku, dan perbuatan individu dalam mencapai hasil yang lebih baik, kemampuan untuk dapat meyakini mana yang baik dan mana yang buruk, ia dapat mengambil keputusan yang dirasa paling baik untuk dirinya sehingga modal psikologi kreatif yang ada dalam individu tersebut meningkat. la dapat berpikir positif, memiliki sifat self-efficacy, hope, optimism dan resiliency dalam dirinya, menyakini bahwa keputusan yang ia ambil adalah yang terbaik dan berharap dengan keputusan tersebut dapat menjadi peluang yang baik baginya. Berdasarkan penjelasan tersebut, hipotesis yang dapat diambil yaitu:

$\mathrm{H}_{1}$ : Sensitivitas etis berpengaruh positif terhadap creatif psycap

\section{Creatif Psycap Terhadap Job Performance}


Seperti yang telah dijelaskan sebelumnya, creatif psycap merupakan konstruk baru dalam penelitian akuntansi manajemen, yang terdiri atas kreativitas dan modal psikologis yaitu istilah yang menggambarkan seseorang yang memiliki kemampuan kreatif dan selalu berpikir positif yang ditandai dengan self efficacy, hope, optimism dan resiliency yang dalam menghadapi permasalahan mampu untuk mencari peluang di lingkungan yang kompetitif.

Sedangkan kinerja pegawai (job performance) dapat diartikan sebagai sejauh mana seseorang melaksanakan tanggung jawab dan tugas kerjanya. Kinerja pegawai adalah hasil kerja secara kualitas dan kuantitas yang dicapai oleh seorang karyawan dalam melaksanakan tugasnya sesuai dengan tanggung jawab yang diberikan kepadanya (Singh et al., 1996) dalam (Solehah, Galih, \& Tamsil, 2013).

Di dalam lingkungan kerja, pegawai dituntut untuk dapat memberikan hasil yang terbaik sehingga terkadang muncul tekanan dan rasa pesimis, namun jika pegawai memiliki modal psikologi kreatif, ia akan mempunyai inisiatif dan ide kreatif untuk meningkatkan kemampuan organisasi dalam merespon peluang yang ada secara tidak langsung modal psikologis (self efficacy, hope, optimism dan resiliency) akan timbul dan membuat kinerja akan meningkat. Seperti penelitian yang dilakukan oleh (Venkatessh \& Blaskovich, 2012) dengan judul the mediating effect of psychological capital on the budget participation-job performance relationship yang menemukan bahwa psychological capital berpengaruh positif terhadap job performance.

Sama halnya dengan yang dilakukan oleh (Liwarto \& Kurniawan, 2015) dalam penelitiannya dengan judul hubungan psycap dengan kinerja karyawan PT.X Bandung yang menemukan hasil bahwa modal psikologi (PsyCap) secara keseluruhan dari karyawan berhubungan positifdan signifikan dengan kinerja individual karyawan. PsyCap seseorang menjadi modal utama untuk membangun perilaku positif dalam bekerja. Berdasarkan penjelasan tersebut, hipotesis yang dapat diambil yaitu: 
$\mathrm{H}_{2}$ : Creatif Psycap berpengaruh positif terhadap Job performance

\section{Sensitivitas Etis Terhadap Job Performance}

Sensitivitas moral atau etika adalah kemampuan untuk mengidentifikasi masalah etis dan memahami konsekuensi etis dari keputusan yang dibuat (Mamik \& Tadjang, 2015). Masalah yang berhubungan dengan etika yang dimaksud adalah bagaimana seseorang meyakini pilihan antara yang baik dan buruk yang akan berpengaruh terhadap keputusan yang ia buat. Dalam hubungannya dengan kinerja pegawai (job performance),pemahaman etika akan mengarahkan sikap, tingkah laku, dan perbuatan individu dalam mencapai hasil yang lebih baik sehingga kinerja pegawai akan meningkat juga.

Hal tersebut sejalan dengan penelitian yang dilakukan oleh (Ariyanto \& Jati, 2010) dimana ia menguji pengaruh independensi, kompetensi, dan sensitivitas etika profesi terhadap produktivitas kerja auditor eksternal (studi kasus pada auditor perwakilan BPK RI Provinsi Bali) menunjukkan hasil bahwa independensi, kompetensi dan sensitivitas etika profesi terbukti berpengaruh positif dan signifikan terhadap produktivitas kerja auditor eksternal pada Perwakilan BPK RI Provinsi Bali. Berdasarkan penjelasan tersebut, hipotesis yang dapat diambil yaitu:

$\mathrm{H}_{3}$ : Sensitivitas etis berpengaruh positif terhadap job performance

\section{METODE PENELITIAN}

\section{Lokasi Penelitian}

Penelitian dilakukan Kota Jayapura dengan mengambil data dari seluruh Rumah sakit yang ada, baik rumah sakit yang dikelola oleh pemerintah maupun oleh non pemerintah (swasta). Ada 7 (tujuh) Institusi rumah sakit yaitu: Rumah Sakit Umum Daerah Dok2, Rumah Sakit Umum Daerah Abepura, Rumah Sakit Umum Daerah Yowari, Rumah Sakit Bhayangkara, Rumah Sakit Marthen Indey, Rumah Sakit Angkatan Laut dan Rumah Sakit Swasta Dian Harapan.

\section{Populasi dan Sampel Penelitian}




\section{Populasi Penelitian}

Populasi merupakan wilayah generalisasi yang terdiri atas objek yang mempunyai kuantitas dan karakteristik tertentu yang ditetapkan oleh peneliti untuk dipelajari dan kemudian ditarik kesimpulannya (Sugiyono, 2007). Populasi dalam penelitian ini adalah para para pengelola rumah sakit.

\section{Sampel Penelitian}

Sampel adalah bagian dari jumlah dan karakteristik yang dimiliki oleh populasi tersebut (Sugiyono, 2007) Teknik pengambilan sampel yang digunakan adalah non probability sampling. Salah satu teknik non probability sampling yang digunakan adalah accidental sampling. Accidental sampling merupakan metode penentuan sampel berdasarkan kebetulan yaitu siapa saja yang secara accidental bertemu dengan peneliti dapat digunakan sebagai sampel, apabila orang yang kebetulan ditemui cocok sebagai sumber data (Sugiyono, 2007).

\section{Jenis dan Sumber Data} Jenis Data

Jenis data dalam penelitian ini adalah penelitian deskriptif dan kuantitatif, data yang diperoleh dari sampel populasi penelitian. Penelitian deskriptif merupakan penelitian untuk mengetahui nilai suatu variabel dengan variabel lainnya atau menghubungkan dengan variabel lain, sedangkan penelitian kuantitatif merupakan penelitian yang memperoleh data dalam bentuk angka ataupun data kualitatif yang diangkakan (Sugiyono, 2007).

\section{Sumber Data}

Sumber data yang digunakan dalam penelitian ini adalah menggunakan data primer yang merupakan data penelitian yang diperoleh langsung dari sumbernya. Data primer tersebut berupa data jawaban kuesioner yang diisi oleh responden.

\section{Variabel Penelitian dan Defini Operasional Penelitian}


Setelah menentukan variabel mana yang menjadi variabel dependen dan variabel independen, selanjutnya menentukan definisi operasional dari variabel penelitian yang akan digunakan dalam penelitian ini. Definisi operasioan variabel penelitian dijelaskan di bawah ini.

\section{Psychological capital}

Psychological capital yang dimaksud dalam penelitian ini, sebagai sebuah kondisi perkembangan psychological state positif dari seseorang dengan karakteristik (1) memiliki keyakinan terhadap kemampuan diri dalam mengambil dan mengerahkan usaha yang cukup agar berhasil dalam melakukan tugas-tugas yang menantang (self-efficacy); (2) membuat atribusi yang positif tentang kesuksesan di masa kini dan masa depan (optimisme); (3) memiliki harapan dalam mencapai tujuan dan bila perlu mengalihkan jalan atau mencari jalan lain untuk mencapai tujuan (hope); dan (4) ketika dihadapkan pada masalah dan halangan dapat bertahan dan bangkit kembali, bahkan melebihi untuk mencapai kesuksesan (resiliency). Dapat diukur dengan menggunakan psychological capital questionnaire 24 (PCQ-24) yang terdiri dari empat aspek yaitu: self-efficacy, optimism, hope, resiliency.

\section{Sensitivitas Etis}

Sensitivitas yang dimaksudkan dalam penelitian ini adalah kemampuan untuk menyadari adanya nilai-nilai etika dalam suatu keputusan. Sensitivitas etika diukur dengan memodifikasi skenario sensitivitas etika Shaub (1993) yaitu: kegagalan akuntan dalam mengerjakan pekerjaan sesuai dengan waktu yang diminta, penggunaan jam kantor untuk kepentingan pribadi, subordinasi judgement akuntan dalam hubungannya dengan prinsip-prinsip akuntansi, pada skala Likert 1 sampai 7 digunakan untuk menunjukkan respon dari kriteria sensitivitas (1 sangat tidak setuju sampai 7 - sangat setuju ). Semakin tinggi nilai skala menunjukkan semakin tinggi sensitivitas etika. 


\section{Job Performance}

Pengukuran berdasarkan perilaku lebih menekankan pada cara atausarana (means) dalam mencapai tujuan, dan bukan pada pencapaian hasilakhir. Pengukuran berdasarkan perilaku condong pada aspek kualitatifdaripada aspek kuantitatif yang terukur. Pengukuran berdasarkan perilaku umumnya bersifat subyektif dimana diasumsikan karyawan dapat menguraikan dengan tepat kinerja yang efektif untuk dirinya sendiri maupun untuk rekan kerjanya (Gomes, 1995). Pengukuran berdasarkan perilaku mendapat perhatian luas dari penelitian-penelitian mengenai perilaku organisasi dan sumber daya manusia karena terbukti skala pengukuran subyektif mempunyai konsistensi (reliabilitas) yang tidak kalah dengan pengukuran obyektif (Sing et al., 1996)

\section{Pengujian Hipotesis}

Analisis data dalam penelitian ini menggunakan pendekatan Structural Equation Model (SEM) dengan metode Partial Least Square (PLS) dengan menggunakan solfware WarpPLS. PLS adalah model persamaan struktural (SEM) yang berbasis komponen atau varian (variance). Menurut Ghozali (2006) PLS merupakan pendekatan alternatif yang bergeser dari pendekatan SEM berbasis covariance menjadi berbasis varian.SEM yang berbasis kovarian umumnya menguji kausalitas/teori sedangkan PLS lebih bersifat predictive model.

Wold dalam Wiyono (2011:395) menyatakan PLS merupakan metode analisis yang powerfull karena tidak didasarkan pada banyak asumsi. Misalnya, data harus terdistribusi normal dan sampel yang tidak harus besar. Selain dapat digunakan untuk mengkonfirmasi teori, PLS juga dapat digunakan untuk menjelaskan ada tidaknya hubungan antar variabel laten. PLS dapat sekaligus menganalisis konstruk yang dibentuk dengan indikator reflektif dan formatif. Hal ini tidak dapat dilakukan oleh SEM yang berbasis kovarian karena akan menjadi unidentified model. Langkahlangkah analisis PLS sebagai berikut: 
1) Merancang Model Struktural (inner model)

2) Merancang Model Pengukuran (outer model)

3) Mengkonstruksi diagram Jalur

4) Konversi diagram Jalur ke dalam Sistem Persamaan

5) Estimasi

6) Goodness of fit

\section{HASIL DAN PEMBAHASAN}

\section{Desain Penelitian}

Di wilayah kota Jayapura terdapat 7 rumah sakit yang dijadikan lokasi penelitian. Responden dalam penelitian ini sebagian besar adalah staf rumah sakit bagian keuangan/administrasi dan program yang terlibat dalam menyusun anggaran. Peneliti menyebarkan sebanyak 60 kuesioner dengan asumsi masing-masing rumah sakit memiliki responden sebanyak 10 orang sebagai aspek pemerataan. Jumlah kuesioner yang dikembalikan adalah sebanyak 38 kuesioner dan terdapat 22 kuesioner yang tidak dikembalikan. Tingkat pengembalian kuesioner ini sebesar $63 \%$.

\section{Uji Outer Model}

Setelah mengeliminasi beberapa indikator yang tidak memenuhi syarat, maka didapat indikator-indikator konstruk yang memenuhi nilai convergent validitydengan faktor loading $>0,5$.Selain itu, hasil uji discriminant validity menunjukkan bahwa nilai korelasi konstruk dengan item pengukuran lebih besar daripada ukuran konstruk lainnya, maka hal tersebut menunjukkan konstruk laten telah memprediksi ukuran pada blok variabel konstruk lebih baik daripada ukuran pada blok lainnya, uji Average Variance Extracted (AVE) juga menunjukkan nilai AVE seluruh variabel lebih besar atau sama dengan 0,5 dimana nilai AVE sensitivitas etis sebesar 0,7 nilai AVE Kinerja sebesar 0,8 dan nilai AVE psychological capital sebesar 0,5 
Uji composite reliability seluruh variabel penelitian lebih besar dari 0,5 . Variabel sensitivitas etis sebesar 0,8. Untuk variabel kinerja mempunyai nilai 0,891 dan untuk psycologi capital sebesar 0,835 .

\section{Uji Inner Model}

Selain itu, dilakukan juga uji inner model dengan melihat nilai $\mathrm{R}$ Square, dimana koefisien determinasi R-square menunjukkan bahwa variabel kinerja mampu dijelaskan oleh sensitivitas etis sebesar $72,1 \%$ dan sisanya $27,9 \%$ dijelaskan faktor lain yang tidak ada dalam model sedangkan psychological capital mampu dijelaskan oleh sensitivitas etis sebesar $14,4 \%$ dan sisanya dijelaskan oleh faktor lain di luar model sebesar $85,6 \%$.

Disamping melihat nilai R-square, suatu model dianggap mempunyai nilai predictive yang relevan jika nilai Q-square lebih besar dari $0(>0)$. Nilai predictive relevance diperoleh dengan rumus sebagai berikut:

$\mathrm{Q}^{2}=1-\left(1-\mathrm{R} 1^{2}\right)\left(1-\mathrm{R} 2^{2}\right)$

$\mathrm{Q}^{2}=1-\left(1-0,57^{2}\right)\left(1-0,52^{2}\right)$

$\mathrm{Q}^{2}=1-(1-0,325)(1-0,270)$

$\mathrm{Q}^{2}=1-(0,675)(0,73)$

$\mathrm{Q}^{2}=1-0,49$

$Q^{2}=0,51$

Hal ini menyatakan bahwa penelitian ini layak untuk menjelaskan variabel endogen yaitu kinerja. Hasil pengolahan data Warp PLS adalah sebagai berikut:

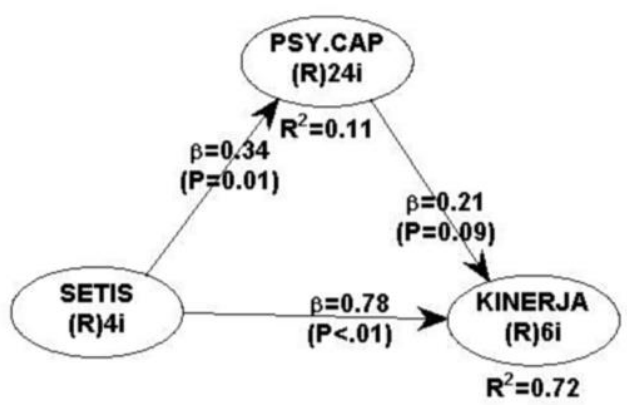

Sumber : Data diolah 2017 


\section{Pengujian Hipotesis}

\section{Sensitivitas Etis Terhadap Creatif Psycap}

Hasil pengujian statistik menunjukkan nilai $p$ value $<0,05$ yaitu sebesar 0,01 . Hal ini bermakna bahwa hipotesis pengarih sensitivitas etis terhadap psicologi capital diterima. Hasil ini menunjukkan bahwa variabel sensitivitas etis merupakan kemampuan seseorang dalam mengidentifikasi masalah yang berhubungan dengan etika yaitu keyakinan memilih antara mana yang baik dan mana yang buruk agar dapat menentukan keputusan nantinya. Sedangkan creatif psycap merupakan istilah yang menggambarkan seseorang yang memiliki kemampuan kreatif dan selalu berpikir positif dalam menghadapi permasalahan serta mampu untuk mencari peluang di lingkungan yang kompetitif.

Kondisi ini juga memberikan pemahaman etika akan mengarahkan sikap, tingkah laku, dan perbuatan individu dalam mencapai hasil yang lebih baik, kemampuan untuk dapat meyakini mana yang baik dan mana yang buruk, ia dapat mengambil keputusan yang dirasa paling baik untuk dirinya sehingga modal psikologi kreatif yang ada dalam individu tersebut meningkat. la dapat berpikir positif, memiliki sifat self-efficacy, hope, optimism dan resiliency dalam dirinya

\section{Creatif Psycap Terhadap Job Performance}

Hasil pengujian statistik menunjukkan nilai $p$ value $<0,05$ yaitu sebesar 0,09. Hal ini bermakna bahwa hipotesis pengaruh Creatif Psycap Terhadap kinerja diterima. Seperti yang telah dijelaskan sebelumnya, creatif psycap merupakan konstruk baru dalam penelitian akuntansi manajemen, yang terdiri atas kreativitas dan modal psikologis yaitu istilah yang menggambarkan seseorang yang memiliki kemampuan kreatif dan selalu berpikir positif yang ditandai dengan self efficacy, hope, optimism dan resiliency yang dalam menghadapi permasalahan mampu untuk mencari peluang di lingkungan yang kompetitif.

Oleh sebab itu pengaruh psikologi terhadap kinerja pegawai (job performance) sangat penting. Hal ini bermakna sejauh mana seseorang 
melaksanakan tanggung jawab dan tugas kerjanya secara kualitas dan kuantitas yang dicapai oleh seorang karyawan dalam melaksanakan tugasnya sesuai dengan tanggung jawab yang diberikan kepadanya (Singh et al., 1996) dalam (Solehah, Galih, \& Tamsil, 2013).

\section{Sensitivitas Etis Terhadap Job Performance}

Hasil pengujian statistik menunjukkan nilai $p$ value $<0,05$ yaitu sebesar 0,01 . Hal ini bermakna bahwa hipotesis pengaruh sensitivitas etis terhadap kinerja diterima. Masalah yang berhubungan dengan etika yang dimaksud adalah bagaimana seseorang meyakini pilihan antara yang baik dan buruk yang akan berpengaruh terhadap keputusan yang ia buat. Dalam hubungannya dengan kinerja pegawai (job performance), pemahaman etika akan mengarahkan sikap, tingkah laku, dan perbuatan individu dalam mencapai hasil yang lebih baik sehingga kinerja pegawai akan meningkat juga.

\section{KESIMPULAN}

Pengaruh sensitivitas etis terhadap creatif psycap menunjukkan hasil yang positif dan signifikan. Hal ini menunjukkan bahwa pentingnya kepekaan etis di dalam meningkatkan modal psikologi karyawan. Kondisi ini juga menjelaskan pentingya sensitivitas etis dalam organisasi seperti runah sakit.

Pengaruh creatif psycap terhadap job performance menunjukkan hasil yang positif dan signifikan. Hasil ini menggambarkan bahwa untuk meningkatkan kinerja karjawan perlu adanya modal psikoligis. Modal ini memberikan nilai postif bagi peningkatan motivasi dan semangat kerja.

Pengaruh sensitivitas etis terhadap job performance menunjukkan hasil yang positif dan signifikan. Hasil ini memberikan gambaran bahwa kinerja karyawan dipengaruhi oleh sensitivas etis. Instituti rumah sakit perlu mempertimbangkan variabel ini dalam program peningkatan kinerja. 


\section{KETERBATASAN}

Penyebaran kuesioner masih memiliki kendala dalam prosedur perizinan dan pengisian kuesioner. Hal tersebut menyebabkan data yang diolah kurang optimal,

Dari 60 kuesioner yang disebar, hanya 38 kuesioner yang kembali tepat waktu. Sebesar 22 kuesioner tidak kembali dikarenakan sibuknya staf rumah sakit,

Metode yang digunakan dalam pengambilan sampel adalah melalui kuesioner sehingga kesimpulan hanya diambil berdasarkan data yang telah diambil melalui penggunaan instrumen secara tertulis,

Penelitian ini menyamaratakan seluruh rumah sakit yang ada, tanpa membedakan apakah rumah sakit tersebut milik pemerintah atau milik swasta, sedangkan penetapan anggaran dari dua jenis rumah sakit tersebut tidaklah sama, dimana biaya operasional dan biaya pemeliharaan rumah sakit swasta harus ditanggung sendiri, berbeda dengan rumah sakit pemerintah yang kedua biaya tersebut dianggarkan dari APBD. Selain itu penelitian ini tidak dapaT melakukan uji beda dikarenakan terbatasnya jumlah dan lingkup rumah sakit yang ada di kota Jayapura.

\section{DAFTAR PUSTAKA}

Ariyanto, D., \& Jati, A. M. (2010). pengaruh independensi, kompetensi, dan sensitivitas etika profesi terhadap produktivitas kerja auditor eksternal (studi kasus pada auditor perwakilan BPK RI provinsi Bali). Diambil kembali

dari http://ojs.unud.ac.id/index.php/jiab/article/download/2625/1837

Djuhaeni, H. (2006). Sistem Penganggaran Rumah Sakit. Unpad. Diambil kembali http://repository.unpad.ac.id/3092/1/sistem_penganggaran_rs.pdf

Falah, S. (2006). Pengaruh Budaya Etis Organisasi dan Orientasi Etika Terhadap Sensitivitas Etika (Studi Empiris Tentang Pemeriksaan Internal di Bawasda Pemda Papua). Tesis Universitas Diponegoro. 
Kartikasari, P. D. (2012). Analisis Faktor-Faktor Yang Mempengaruhi Sensitivitas Etika (Studi Pada Inspektorat Provinsi Jawa Tengah). Skripsi Universitas Diponegoro.

Liwarto, I. H., \& Kurniawan, A. (2015). Hubungan Psycap Dengan Kinerja Karyawan PT.X Bandung. Jurnal Manajemen, 14.

Luthans, F., Youssef, C. M., \& Avolio, B. J. (2007). Psychological Capital : Developing the Human Competitive Edge. Oxford University Press, Inc.

Mamik, \& Tadjang, M. D. (2015). Sensitivitas Etis Dan Sikap Kepatuhan Wewenang Terhadap Kinerja Bidan Dalam Melakukan Rujukan Di Kabupaten Gresik. Prosiding Seminar Nasional Kesehatan. Politeknik Kesehatan Kementerian Kesehatan Surabaya.

Mudayana, A. A. (2010). Pengaruh Motivasi dan Beban Kerja Terhadap Kinerja Karyawan Rumah Sakit Nur Hidayah Bantul. KES MAS, 04.Use the "Insert Citation" button to add citations to this document.

Muttaqin, A. Z. (2014). Analisis Faktor-Faktor Yang Mempengaruhi Sensitivitas Etika Auditor Pemerintah. Skripsi Universitas Diponegoro.

Nurdin, R., Darmawansyah, \& Indar. (2010). Pengaruh Gaya Kepemimpinan dan Kepuasan Kerja Terhadap Kinerja Pegawai di RSUD Namlea Kabupaten Buru Provinsi Maluku. Diambil kembali dari

http://pasca.unhas.ac.id/jurnal/files/05f176bbdd853197b5ba9edc52b 23001.pdf

Nurfaizal, Y. (2016). Modal Psikologis Kreatif Creative Psychological Capital (CrePsyCap). Jurnal Pro Bisnis, STMIK Amikom Purwokerto. Diambil kembali dari http://ejournal.amikompurwokerto.ac.id/index.php/probisnis/article/do wnload/442/392

Silen, A. P. (2016). Pengaruh Modal Psikologis dan Keterlibatan Pegawai Terhadap Kinerja Pegawai Dengan Kepuasan Kerja Sebagai Variabel Mediasi (Studi Pegawai Politeknik IImu Pelayaran Semarang). Jurnal Manajemen Teori dan Terapan.

Soleha, N., Rosiana, R., \& Yulianto, A. S. (2014). Pengaruh Mediasi Modal Psikologi Pada Hubungan Perencanaan Anggaran Dan Kinerja Pegawai (Studi Empiris Pada PNS Pemerintah Provinsi Banten). Jurnal Akuntansi, 18, 188-201.

Solehah, N., Galih, \& Tamsil, L. (2013). The Effect of Budgetary Participation on Job Performance with Psychological Capital and Organizational Commitment as an Intervening Variable. Simposium Nasional Akuntansi XIV. 
Venkatessh, R., \& Blaskovich, J. (2012). The Mediating Effect of Psychological Capital On The Budget Participation-Job Performance Relationship. Journal Of Management Accounting Research, 24, 159-175. 